\title{
30. PALEOCEANOGRAPHIC IMPLICATIONS OF A 17-M.Y.-LONG RECORD OF HIGH-LATITUDE MIOCENE CALCAREOUS NANNOPLANKTON FLUCTUATIONS1
}

\author{
Luc Beaufort ${ }^{2}$ and Marie-Pierre Aubry ${ }^{2}$
}

\begin{abstract}
A record based on counts of the relative abundance of the dominant calcareous nannofossil taxa Coccolithus pelagicus and Reticulofenestra spp. in sediments recovered from Ocean Drilling Program Hole 747A (Kerguelen Plateau, Southern Indian Ocean) is established in this paper. This record (17 m.y. long) virtually spans the entire Miocene. Broad, steplike variations in the abundance of $C$. pelagicus range between $0 \%$ and $96 \%$. Based on these variations, five stratigraphic units characterized by high abundance in $C$. pelagicus are delineated. We suggest that these variations are caused by water-mass movements (such as the north/south shifting of a front). This pronounced signal is compared with paleoceanographic events revealed by isotopic $\left(\delta^{18} \mathrm{O}\right.$ and $\left.\delta^{13} \mathrm{C}\right)$ studies. The five defined units are tentatively correlated to well-known global isotopic events. In particular, Units A and D correlate respectively with the Oligocene/Miocene boundary glaciation and the middle Miocene cooling event. Time-series analysis indicates the presence of the three main periodic components of the eccentricity of the Earth's orbit. A $200-\mathrm{k}$.y. cycle is also present. The stratigraphic and paleoceanographic significance of this record is discussed.
\end{abstract}

\section{INTRODUCTION}

The Antarctic Ocean ecosystem is subject to extreme conditions that control the nature and distribution of the phytoplankton community (e.g., Priddle et al., 1986). In this ecosystem, the most influential ecologic factors are temperature, irradiance, concentration of nutrients, and depth of the mixed layer (Priddle et al., 1986). One can expect to retrace the history of the Antarctic paleoecosystem through the study of its fossil phytoplankton, in relation to the development of severe climate conditions as Antarctica became glaciated (i.e., at least since the early Oligocene; Miller and Fairbanks, 1985; Zachos et al., this volume),

At: Ocean Drilling Program (ODP) Sites 747, 748, and 751, the Miocene calcareous nannofossil assemblages are poorly diversified. Coccolithus pelagicus and species of the genus Reticulofenestra ( $R$. minutula-pseudoumbilica group, $R$. perplexa, and $R$. floridanus [in the lower Miocene]) represent at least $95 \%$ of the calcareous nannoflora. Other taxa are Sphenolithus sp. cf. S. moriformis, Calcidiscus macintyrei, and Helicosphaera sp. cf. H. granulata. Because these latter are so few, the abundance of $C$. pelagicus vs. Reticulofenestra spp. approximates the abundance of $C$. pelagicus in the whole nannoflora. It is instructive to count the abundance of $C$. pelagicus because it is often regarded as a cool-water species and, therefore, can be a good tracer of water masses. Site 747 has been selected for this study because its relative stratigraphic continuity permits a long, detailed, and continuous record of the variations of the abundance of $C$. pelagicus.

\section{SITE AND METHOD}

Hole 747A, drilled on the Kerguelen Plateau (Southern Indian Ocean, $54^{\circ} 49^{\prime} \mathrm{S}, 76^{\circ} 48^{\prime} \mathrm{E}$ ) (Fig. 1), provides an almost continuous section throughout the Neogene. A good magnetostratigraphic control is available from the Oligocene/Mio-

\footnotetext{
${ }^{1}$ Wise, S. W., Jr., Schlich, R., et al., 1992. Proc. ODP, Sci. Results, 120: College Station, TX (Ocean Drilling Program).

2 URA 11, Centre de Paléontologie Stratigraphique et Paléoécologique, Département des Sciences de la Terre, Université de Lyon I, 27-43 Blvd. du 11 Novernbre, 69622 Villeurbanne, France, and Woods Hole Oceanographic Institution, Woods Hole, MA 02543, U.S.A.
}

cene boundary to the lower upper Miocene (Heider et al., this volume). The average sedimentation rate of the mainly uniform nannofossil ooze is about $5 \mathrm{~m} / \mathrm{m}$.y. (Shipboard Scientific Party, 1989).

To establish a sufficiently detailed record, smear slides were prepared from samples taken every $10 \mathrm{~cm}$ in an interval from 42 to 132 mbsf (Samples $120-747 \mathrm{~A}-5 \mathrm{H}-4,5 \mathrm{~cm}$, to $-14 \mathrm{H}-7,50 \mathrm{~cm})$. About 900 samples were analyzed. The first 200 placoliths encountered while scanning a slide were recorded and the percentage of $C$. pelagicus vs. Reticulofenestra spp. was calculated as follows: (number of $C$. pelagicus/[number of $R$. pseudoumbilica + number of $C$. pelagicus $]) \times 100$.

Using this methodology, the percentage varies solely with processes (ecologic and/or taphonomic) exclusively controlling the abundance of the two species. It does not vary, in particular, with fluctuations in the flux of terrigenous material. Coccoliths in both groups are of about the same size and shape. They are placoliths, a kind of coccolith most resistant to dissolution. The relative frequencies between the two species are unlikely to be biased by differential (e.g., winnowing) or chemical (e.g., dissolution) processes. The coccoliths are transported to the abyss by means of fecal pellets, and it is thought that the composition of these latter reflect faithfully the original nannoplankton community (Honjo, 1976). For these reasons, we assume that the percentages established are not biased to a significant degree by taphonomic processes in relation to the original percentages in the phytoplankton. Therefore, they probably reflect the state of the ecologic environment in which the organisms lived.

\section{STRATIGRAPHY AND CHRONOLOGY}

The stratigraphic and chronologic framework on which this study is based results from an integration of the magnetobiostratigraphic data with the global polarity time scale of Berggren et al. (1985) (Shipboard Scientific Party, 1989; Heider et al., this volume). In the interval from 42 to $132 \mathrm{mbsf}, 43$ reversals were identified. Isotope stratigraphy (Wright and Miller, this volume) essentially confirms the interpretation of the magnetostratigraphy (Heider et al., this volume), and only a few problems remain relative to the interpretation of the upper Miocene record. Following Heider et al. (this volume), 


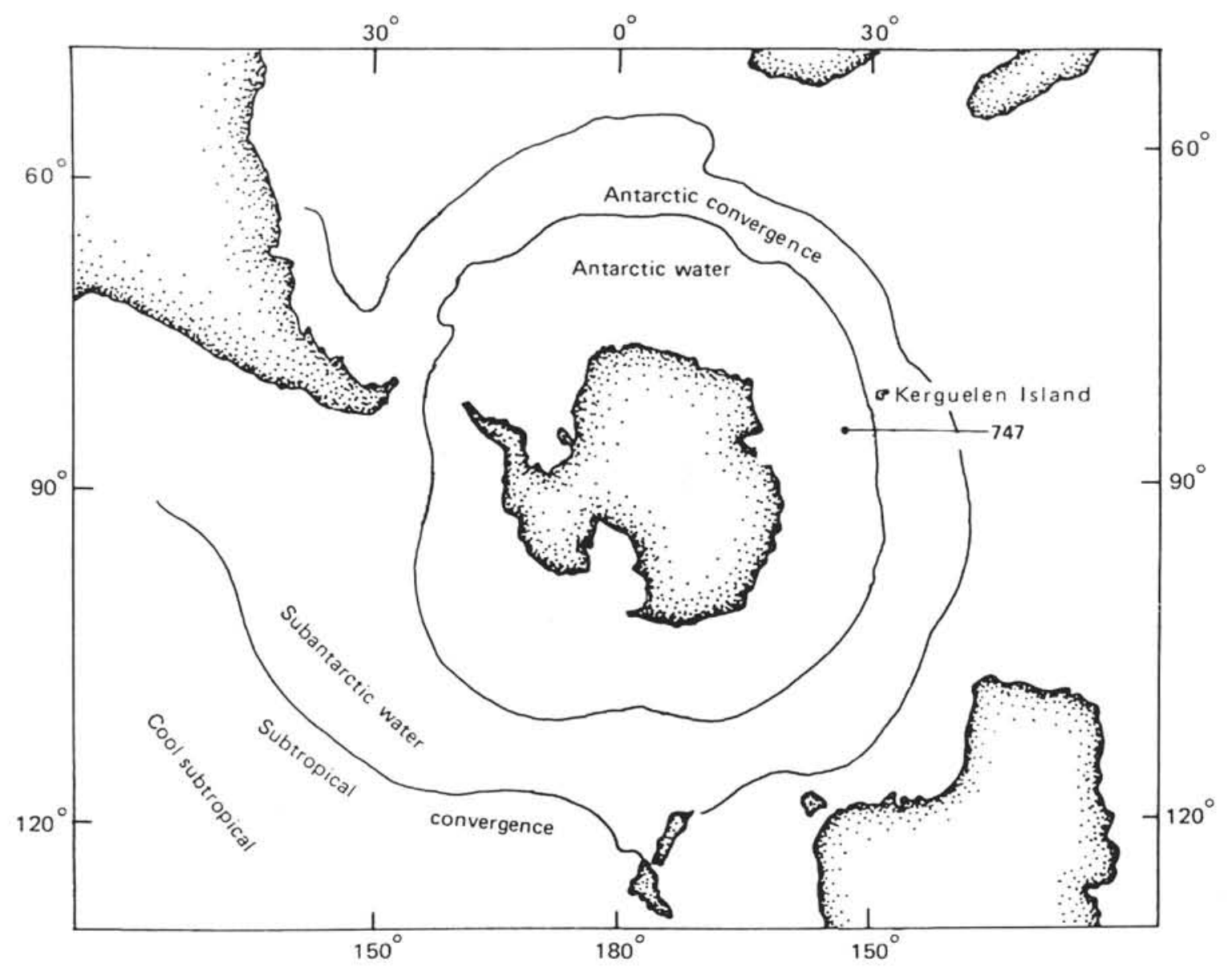

Figure 1. Location of Hole 747A, Leg 120.

the short normal event present in Core 120-747A-5H (42.3$43.05 \mathrm{mbsf}$ ) is interpreted in this study as the lower normal part of Subchron 4A. It bears an age of $8.41 \mathrm{Ma}$. An unconformity at $\approx 41$ mbsf prevented us from precisely dating Miocene calcareous nannofossil assemblages younger than about $8.4 \mathrm{Ma}$.

The sedimentation rate in the Miocene interval studied (42-127.5 mbsf) averages $5.5 \mathrm{~m} / \mathrm{m}$.y. As samples were taken at $10-\mathrm{cm}$ intervals, the time span between consecutive samples is on the order of $18 \mathrm{k} . \mathrm{y}$. The age model used in this study is based on the linear interpolation between the ages of the 43 reversals and provides a calibration point roughly every 400 k.y. This age model is well constrained with respect to the sampling interval.

\section{FLUCTUATION OF THE PERCENTAGE OF COCCOLITHUS PELAGICUS/RETICULOFENESTRA SPP.}

\section{Analysis}

The results of the counting are shown in Figures 2 and 3 and in Table 1 . The percentage of $C$. pelagicus shows extremely broad variations ranging from $0 \%$ to $96 \%$ (Figs. 1 and 2). Long periods dominated by $C$. pelagicus alternate with long intervals during which this species is a marginal component of the assemblages. The average percentage of $C$. pelagicus is $34 \%$. The units are defined as corresponding to intervals at least $1 \mathrm{~m}$ thick, where the percentage of $C$. pelagicus is higher than the average. Five intervals fit this criterion and are labeled by capital letters (Figs. 2 and 3; Table 2).

\section{Discussion}

The present distribution of Coccolithus pelagicus reflects an affinity for cool water. This species is restricted to high latitudes where it is known in the North Atlantic (McIntyre and Bé, 1967), the North Pacific (Geitzenauer et al., 1976), and the South Pacific (Nishida, 1979). Okada and McIntyre (1979) indicate that Coccolithus pelagicus is a stenothermal species adapted to water temperatures from $0^{\circ}$ to $15^{\circ} \mathrm{C}$ (with optimum abundance between $2^{\circ}$ and $12^{\circ} \mathrm{C}$ ). Large fluxes of C. pelagicus in samples collected during winter and spring in the Arctic Sea, where the temperature is around $-1.75^{\circ} \mathrm{C}$ (Honjo, in press), reflect the adaptability of $C$. pelagicus to cold waters. The latitudinal distribution of $C$. pelagicus throughout the entire Neogene suggests that $C$. pelagicus did not change its ecological affinity since the beginning of the Miocene (Haq, 1980). Bukry (1980) showed that the abundance pattern of $C$. pelagicus does not exactly follow a latitudinal gradient in the South Pacific but has been linked to the paths of cold-water currents at least since the late Miocene.

On the contrary, the extinct species $R$. pseudoumbilica and other related species seem to have no distinct ecologic preferences. It is often regarded as cosmopolitan (e.g., Bukry, 1972, 1976). In the North Atlantic, during the Neogene, $R$. pseudoumbilica was most abundant at mid and low latitudes (Haq, 1980).

The extreme minimal and maximal values that the percentage between the two species reaches at Site 747 indicate that the two species had opposite ecological affinities during the 


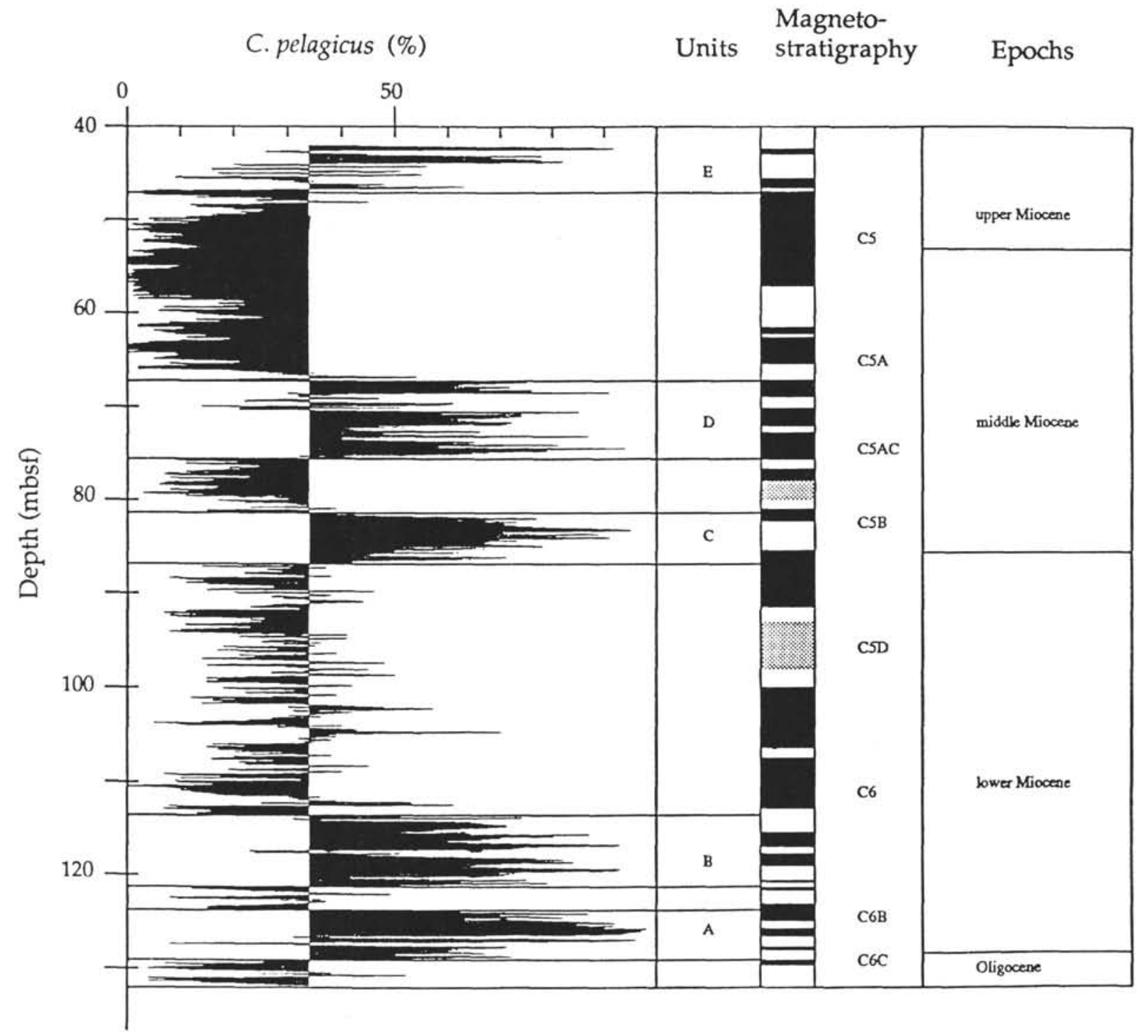

Figure 2. Stratigraphic abundance of Coccolithus pelagicus vs. Reticulofenestra spp. at Hole 747 A. The vertical line at $34 \%$ represents the average of the abundance. The shaded area in the magnetostratigraphic column indicates uninterpretable data or the absence of data.

Miocene. The fact that periods with equal abundance between the two species are rare and correspond only to short transitions between the two types of assemblages suggests that two distinct surface-water masses migrated back and forth over Site 747 throughout the Miocene. It is likely that a front between these two water masses existed during most of the Miocene at the latitude of the Kerguelen Plateau. Hays et al. (1976a) showed that $18,000 \mathrm{yr}$ ago the Antarctic polar front was about $7^{\circ}$ north of its actual position. Although not yet clearly understood, north/south movements of this front have undoubtedly occurred. Site 747 is located about $6^{\circ} \mathrm{S}$ of the Antarctic convergence and about $22^{\circ} \mathrm{S}$ of the subtropical convergence (Fig. 1). Kemp et al. (1975) and Kemp (1978) have suggested that the Miocene polar front was located $10^{\circ} \mathrm{S}$ of its present location, which is south of Site 747, therefore. If the Miocene path of water masses corresponded to the present oceanographic pattern as Kennett et al. (1975) or Kemp (1978) suggested, the Antarctic convergence or the subtropical convergence may have been located around the latitude of Site 747. Another possibility is that instead of a juxtaposition between two water masses, a given water mass experienced successive chemical and/or physical changes (like the presence or absence of upwellings). Although small shifts of a front would easily produce strong local variations in the composition of the phytoplankton, such variations would require very pronounced changes in the quality of a single water mass.

\section{HIGH ABUNDANCE IN COCCOLITHUS PELAGICUS AND THE ISOTOPIC RECORD}

\section{Comparison with the $\delta^{18} \mathrm{O}$}

A strong correlation (same pattern in the records) between the abundance of $C$. pelagicus and isotopic composition $\left(\delta^{18} \mathrm{O}\right.$ and $\delta^{13} \mathrm{C}$ ) of benthic foraminifers is not expected because deep oceanic circulation does not necessary reflect surface circulation (at the Kerguelen Plateau, today's deep-water masses and the surface-water masses are entirely different in nature and in origin; see Gambéroni, 1979). Yet it is interesting to compare such records so as to depict time correlations between events, that is, a link between global events (isotopic records) and local events (abundance of $C$. pelagicus). To have a more 

C. pelagicus $(\%)$
Units stratigraphy
Epochs

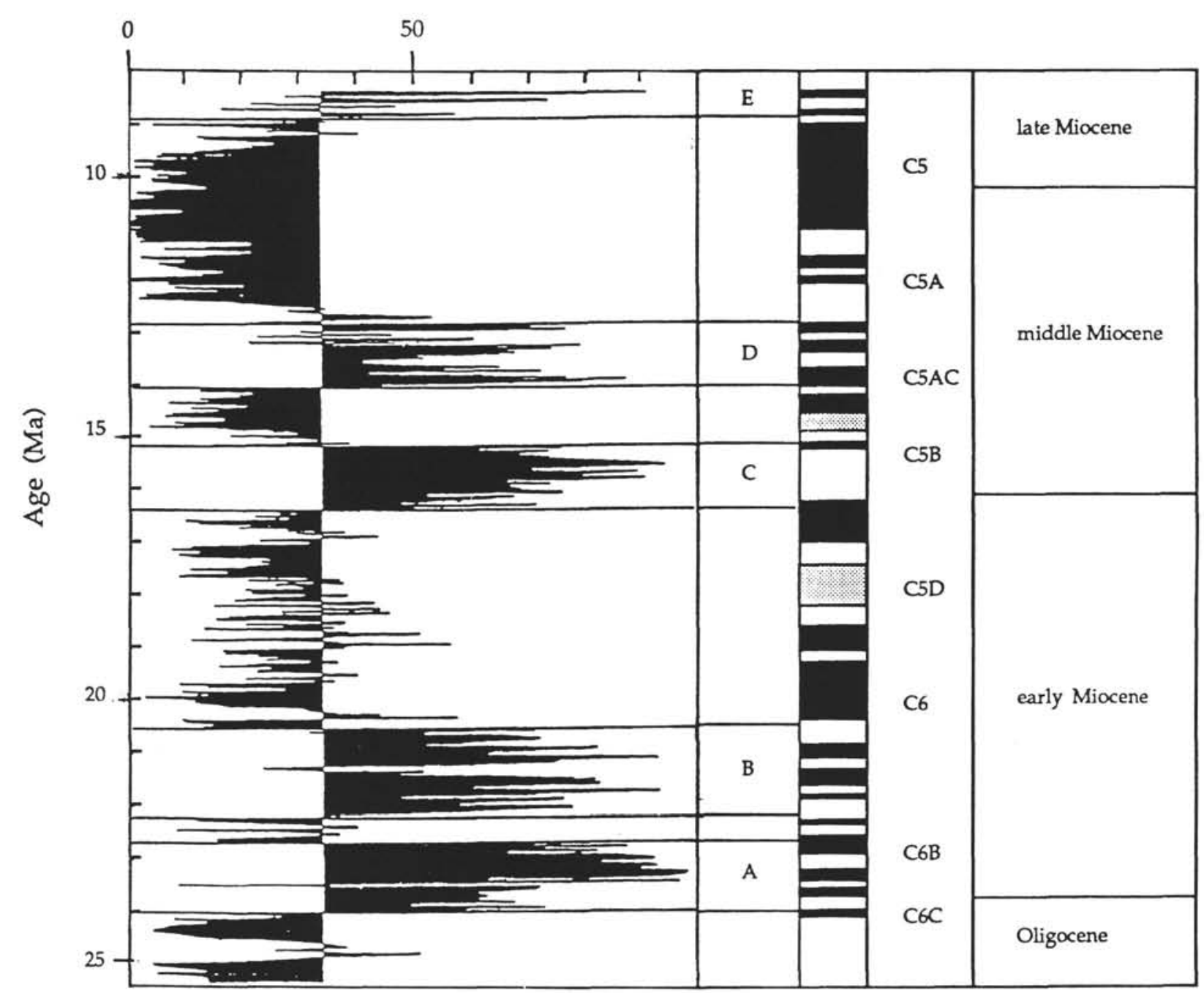

Figure 3. Temporal abundance of Coccolithus pelagicus vs. Reticulofenestra spp. at Hole 747A. The vertical line at $34 \%$ represents the average of the abundance. The shaded area in the magnetostratigraphic column indicates uninterpretable data or the absence of data.

comprehensive history of the global $\delta^{18} \mathrm{O}$ events, records from other sites are used in the comparison.

No isotopic studies on planktonic foraminifers are yet available for the Miocene sediment recovered from Site 747, but Wright and Miller (this volume) have analyzed the isotopic composition of the benthic foraminifers (Fig. 4).

The most dominant feature in the Miocene benthic foraminifers $\delta^{18} \mathrm{O}$ records are (1) heavy values following the Oligocene/Miocene boundary (Shackleton and Kennett, 1975; Miller and Fairbanks, 1985), (2) late early Miocene minimum values (Vincent et al., 1985), and (3) a middle Miocene steplike increase (Vincent et al., 1985) (Fig. 5).

At Site 747, a sharp increase in the percentage of $C$. pelagicus (at the top of Unit A) was observed at the Oligocene/Miocene boundary; this increase correlates to the $\delta^{18} \mathrm{O}$ increase reported from several DSDP and ODP sites, that is, DSDP Sites 277 (Shackleton and Kennett, 1975), 563 and 558 (Miller and Fairbanks, 1985), 522 (Miller et al., 1988), and 366 (Miller et al., 1989), and ODP Site 667 (Miller et al., 1989).
Miller and Fairbanks (1985) interpreted this increase as reflecting a glacial event.

The top of Unit $\mathrm{C}$ corresponds to the minimum oxygen event at 16.5 Ma described by Vincent et al. (1985). In the benthic foraminifer record from Hole 747A (Wright and Miller, this volume, fig. 3), this isotopic event occurs between 90 and 86 mbsf (Fig. 4), whereas Unit C ends at $86.4 \mathrm{mbsf}$.

The prominent middle Miocene cooling event corresponds to an increase of the isotopic values from $1 \%$ to $1.5 \%$ between 14.6 and 12.6 Ma (Vincent et al., 1985). Most authors (Shackleton and Kennett, 1975; Savin et al., 1975; Woodruff et al., 1981; Vincent and Berger, 1985; Miller et al., 1988; among others) explain this event as reflecting first the growth of Antarctica's ice sheet and, second, a deepwater cooling (but see Matthews and Poore, 1980). The $\delta^{18} \mathrm{O}$ record from Hole 747A (Wright and Miller, this volume) shows this increase particularly well between 81 and $63 \mathrm{mbsf}$ (Fig. 4). It is during this important isotopic event that Unit D was deposited. 
For the remainder of the Miocene, the $\delta^{18} \mathrm{O}$ values on benthic foraminifers remain high but fluctuated irregularly (Woodruff and Savin, 1989), whereas the planktonic foraminifer $\delta^{18} \mathrm{O}$ values decreased significantly after $12.6 \mathrm{Ma}$ (Vincent et al., 1985), which correlates exactly with the end of Unit D. The explanation of this drop in the $\delta^{18} \mathrm{O}$ of the planktonic foraminifers is not yet fully understood (cf. Shackleton and Kennett, 1975; Matthews and Poore, 1980; Vincent et al., 1985; Woodruff and Savin, 1989), possibly in part because of the lack of data (few planktonic isotopic records are available for this time interval). At this time, we can only point out this correlation.

\section{Comparison with the $\delta^{13} \mathrm{C}$ Record}

A maximum was observed in every middle Miocene benthic carbon isotope records around 16 Ma (Loutit et al., 1978; Woodruff and Savin, 1985; Vincent et al., 1985; Miller et al., 1989). At Site 747, it occurs at $84 \mathrm{~m}$ (Wright et al., this volume) (Fig. 4). The significance of this event is still a point of discussion, and several explanations have been proposed (cf. Vincent and Berger, 1985; Woodruff and Savin, 1989). Unit $\mathrm{C}$ is tentatively correlated to this event.

Vincent et al. (1985) described two other $\delta^{13} \mathrm{C}$ events in the planktonic foraminifers that correspond to an increase in the $\delta^{13} \mathrm{C}$ around $22.7 \mathrm{Ma}$, followed by a decrease in values around 20.7 Ma. These events correlate with the boundaries of Unit B (Fig. 5).

Oceanographic studies in the Kerguelen area reveal a strong chemical and physical contrast between the surfacewater masses on both sides of a front (Jacques, 1978). Temperature, depth of the mixing layer, salinity, and concentration of nutrients are extremely different (Jacques, 1978). As phytoplanktonic communities are well adapted to the various ecologic factors of their living environment, not only to its temperature, it is suspected that the correlation observed between abundance in C. pelagicus and $\delta^{13} \mathrm{C}$ events at Site 747 reflects intricate relations between water masses and the composition of their phytoplankton.

\section{TIME-SERIES ANALYSIS}

The abrupt variations in the abundance of $C$. pelagicus at Site 747 correlate with important paleoceanographic events as revealed by isotopic studies supports the hypothesis that variations in abundance in $C$. pelagicus reflect water-mass movements. Hays et al. (1976a) showed that the latitudinal position of the Antarctic Polar Front during the Pleistocene was dependent upon climatic fluctuations. The Milankovitch theory of climate, which predicts that global ice volume varies as a function of cycles inherent to the Earth orbital parameters, has been well documented in the last two decades (e.g., Hays et al., 1976b; Imbrie et al., 1984). If the signals observed in the calcareous nannofossil record at Hole $747 \mathrm{~A}$ are linked to climatic variations, an orbital imprint should be detected by a time-series analysis.

The chronologic resolution (with an average of one stratigraphic tie point every 400 k.y.), the sampling density (18 k.y. on average), and the length of the record (17 m.y.) allow a resolution of cyclicity in a period range of 80 to $5000 \mathrm{k} . \mathrm{y}$. Hence, it is possible to test the presence of eccentricity cycles $(95,126$, and $413 \mathrm{k} . \mathrm{y}$.). The sampling interval is too broad to study frequencies higher than about $80 \mathrm{k} . \mathrm{y}$. Also, the presence of obliquity cycles ( $41 \mathrm{k} . \mathrm{y}$.) or precession cycles ( 23 and 19 k.y.) cannot be tested in this series.

\section{Method}

The data were first linearly interpolated to produce a new series equally spaced in time ( $20 \mathrm{k}$.y.) (program TIMER of
SPECMAP). A Fast Fourier Transform (Blackman-Tukey spectral analysis) was performed, using a Hamming window and a prewhitening constant of 0.8 (allowing the removal of the low-frequency components in the data) (POWER, the program used, was written by N. Pisias and has been used by the SPECMAP group).

\section{Results}

The entire series was first analyzed (Fig. 6). The prewhitening method does not remove entirely a large peak centered on 2653 k.y. that dominates the spectrum (on Fig. 6, it was intentionally truncated so as to examine in greater detail the frequency band of interest). The spectrum shows large peaks at $995,444,300,200$, and around 100 k.y. Several peaks are centered on 130 k.y. (144-115 k.y.) and 95 k.y. (102-87 k.y.). It is noteworthy that $130 \mathrm{k} . \mathrm{y}$. and $95 \mathrm{k} . \mathrm{y}$. are close to the two principal terms of the eccentricity cycles, that is, to 123 and 95 k.y. (Berger, 1977). Also, 444 k.y. is close to the 413-k.y. period predicted for the eccentricity. With such a long series, it is possible to check with sufficient accuracy the presence of these periods in a different part of the series. The series was split into four parts, each $5 \mathrm{~m} . \mathrm{y}$. long, with overlaps of $1 \mathrm{~m} . \mathrm{y}$. The four resulting spectra show peaks in the same frequency range $(200,125$, and 95 k.y.) (Fig. 7$)$. The small variations of the periods can easily be explained by imperfections in the chronologic model used (linear interpolation between tie points, for example).

Periods close to the predicted eccentricity cycles are significant and stable in the series. The period close to $413 \mathrm{k} . \mathrm{y}$. found in the spectrum of the entire series shows some variability; in the second subseries, it does not show clear power. Even though the prewhitening technique may have artificially diminished power around $413 \mathrm{k} . \mathrm{y}$., the occurrence of this period in the series cannot be confirmed. A stable and significant component of the five spectra is a 200-k.y. peak. It is not explained by the Milankovitch theory, but it is found in other pre-Pliocene series. For instance, Herbert and Fischer (1986) reported a 225-k.y. cycle from a Cretaceous $\mathrm{CaCO}_{3}$ series; and the Walsh spectra of long isotopic records from Miocene benthic foraminifers show strong $185-\mathrm{k} . \mathrm{y} \cdot\left(\delta^{13} \mathrm{C}\right)$ and 227-k.y. ( $\left.\delta^{18} \mathrm{O}\right)$ peaks (Tiwary, 1987, fig. 3 ).

The presence of significant power close to the eccentricity cycle suggests that the percentage of $C$. pelagicus in the Miocene sediments of the Kerguelen Plateau varied, at least in part, as a function of climatic variations. The frequencies that correspond to the eccentricity, however, are minor compared with a low-frequency component that virtually dominates the spectrum and is not directly explained by orbital forcing.

\section{CONCLUSIONS}

The abundance of Coccolithus pelagicus in the Southern Indian Ocean varied broadly during the Miocene; therefore, the ecological parameters controlling its distribution did as well. Correlation of the abundance record of this cool-water species with global climatic events as indicated by stable isotope studies suggests that important changes in the ecological parameters in the Southern Indian Ocean occurred at times of global climatic and oceanographic changes. The cause of variation, however, is not really understood yet. Until further studies, variation in the composition of the calcareous nannoplankton as a function of water-mass movement represents the best hypothesis. First-order variations observed in this calcareous nannofossil record correspond to time intervals a few million years long dominated by $C$. pelagicus alternating with periods when it was a minor component of the calcareous nannofossil assemblages. A second order of variation (period $<1 \mathrm{~m}$.y.) are periodic fluctuations 
Table 1. Percentage of Coccolithus pelagicus vs. Reticulofenestra spp.

\begin{tabular}{|c|c|c|c|c|c|c|c|c|c|c|c|c|c|c|c|c|c|}
\hline $\begin{array}{l}\text { Depth } \\
\text { (mbsf) }\end{array}$ & C \% & $\begin{array}{l}\text { Depth } \\
\text { (mbsf) }\end{array}$ & $\mathrm{C} \%$ & $\begin{array}{l}\text { Depth } \\
\text { (mbsf) }\end{array}$ & C \% & $\begin{array}{l}\text { Depth } \\
\text { (mbsf) }\end{array}$ & $\mathrm{C} \%$ & $\begin{array}{l}\text { Depth } \\
\text { (mbsf) }\end{array}$ & C \% & $\begin{array}{l}\text { Depth } \\
\text { (mbsf) }\end{array}$ & C \% & $\begin{array}{l}\text { Depth } \\
\text { (mbsf) }\end{array}$ & C \% & $\begin{array}{l}\text { Depth } \\
\text { (mbsf) }\end{array}$ & C \% & $\begin{array}{l}\text { Depth } \\
\text { (mbsf) }\end{array}$ & C \% \\
\hline 42.05 & 44 & 49.80 & 15 & 57.90 & 4 & 65.50 & 10 & 73.30 & 48 & 81.63 & 15 & 89.30 & 26 & 97.20 & 27 & 104.50 & 43 \\
\hline 42.10 & 49 & 49.90 & 4 & 58.00 & 5 & 65.55 & 20 & 73.40 & 35 & 81.79 & 19 & 89.40 & 30 & 97.30 & 42 & 104.60 & 34 \\
\hline 42.20 & 77 & 50.00 & 25 & 58.10 & 3 & 65.60 & 8 & 73.60 & 50 & 81.87 & 22 & 89.60 & 18 & 97.40 & 48 & 104.70 & 70 \\
\hline 42.30 & 88 & 50.10 & 5 & 58.20 & 2 & 65.65 & 7 & 73.70 & 62 & 81.94 & 39 & 89.70 & 15 & 97.55 & 26 & 104.80 & 56 \\
\hline 42.40 & 92 & 50.20 & 5 & 58.30 & 16 & 65.70 & 6 & 73.80 & 65 & 82.02 & 39 & 89.80 & 46 & 97.60 & 19 & 104.90 & 39 \\
\hline 42.50 & 86 & 50.30 & 17 & 58.40 & 3 & 65.75 & 2 & 73.90 & 58 & 82.10 & 48 & 89.90 & 32 & 97.70 & 15 & 105.00 & 39 \\
\hline 42.60 & 47 & 50.40 & 6 & 58.50 & 2 & 65.80 & 5 & 74.00 & 67 & 82.18 & 61 & 90.00 & 20 & 97.80 & 29 & 105.10 & 36 \\
\hline 42.70 & 26 & 50.50 & 1 & 58.60 & 7 & 65.85 & 5 & 74.10 & 81 & 82.26 & 67 & 90.10 & 34 & 97.90 & 30 & 105.20 & 39 \\
\hline 42.80 & 31 & 50.60 & 1 & 58.70 & 22 & 65.90 & 2 & 74.20 & 72 & 82.34 & 77 & 90.20 & 38 & 98.00 & 35 & 105.30 & 36 \\
\hline 42.90 & 45 & 50.70 & 3 & 58.80 & 22 & 65.95 & 2 & 74.30 & 49 & 82.41 & 75 & 90.30 & 37 & 98.10 & 45 & 105.40 & 32 \\
\hline 43.00 & 43 & 50.80 & 6 & 58.90 & 21 & 66.10 & 18 & 74.40 & 75 & 82.49 & 51 & 90.40 & 27 & 98.20 & 33 & 105.55 & 38 \\
\hline 43.10 & 65 & 50.90 & 3 & 59.00 & 17 & 66.20 & 21 & 74.50 & 94 & 82.57 & 68 & 90.50 & 32 & 98.30 & 36 & 105.60 & 36 \\
\hline 43.20 & 78 & 51.00 & 6 & 59.10 & 26 & 66.30 & 26 & 74.60 & 76 & 82.96 & 73 & 90.60 & 29 & 98.40 & 27 & 105.70 & 33 \\
\hline 43.30 & 61 & 51.10 & 0 & 59.20 & 18 & 66.40 & 35 & 74.70 & 79 & 83.04 & 68 & 90.70 & 35 & 98.50 & 27 & 105.80 & 35 \\
\hline 43.40 & 73 & 51.20 & 4 & 59.30 & 21 & 66.50 & 28 & 74.80 & 79 & 83.12 & 68 & 90.80 & 43 & 98.60 & 45 & 105.90 & 31 \\
\hline 43.50 & 73 & 51.30 & 4 & 59.40 & 7 & 66.60 & 30 & 74.90 & 69 & 83.20 & 73 & 90.90 & 44 & 98.70 & 50 & 106.00 & 16 \\
\hline 43.60 & 78 & 51.40 & 4 & 59.50 & 25 & 66.70 & 44 & 75.00 & 63 & 88.27 & 73 & 91.10 & 35 & 98.80 & 23 & 106.10 & 24 \\
\hline 43.70 & 72 & 51.50 & 7 & 59.60 & 18 & 66.80 & 54 & 75.10 & 68 & 88.35 & 78 & 91.20 & 28 & 98.90 & 22 & 106.20 & 22 \\
\hline 43.80 & 82 & 51.60 & 10 & 59.70 & 9 & 66.90 & 48 & 75.20 & 54 & 88.43 & 88 & 91.30 & 27 & 99.05 & 15 & 106.30 & 15 \\
\hline 43.90 & 76 & 51.70 & 11 & 59.80 & 6 & 67.00 & 21 & 75.30 & 32 & 83.51 & 90 & 91.40 & 25 & 99.10 & 19 & 106.40 & 20 \\
\hline 44.00 & 47 & 51.80 & 5 & 59.90 & 11 & 67.10 & 23 & 75.40 & 38 & 83.59 & 93 & 91.50 & 23 & 99.20 & 17 & 106.50 & 18 \\
\hline 44.10 & 20 & 51.90 & 5 & 60.00 & 14 & 67.20 & 35 & 75.50 & 53 & 88.67 & 95 & 91.60 & 33 & 99.30 & 18 & 106.60 & 17 \\
\hline 44.20 & 22 & 52.00 & 10 & 60.10 & 13 & 67.30 & 75 & 75.60 & 37 & 83.74 & 86 & 91.70 & 32 & 99.40 & 15 & 106.70 & 25 \\
\hline 44.30 & 56 & 52.10 & 6 & 60.20 & 17 & 67.40 & 75 & 77.10 & 12 & 83.82 & 69 & 91.80 & 12 & 99.50 & 15 & 106.80 & 20 \\
\hline 44.40 & 36 & 52.20 & 3 & 60.30 & 17 & 67.60 & 63 & 77.17 & 9 & 83.90 & 71 & 91.90 & 11 & 99.60 & 30 & 106.90 & 31 \\
\hline 44.50 & 22 & 52.30 & 6 & 60.40 & 23 & 67.70 & 60 & 77.25 & 19 & 88.98 & 89 & 92.00 & 12 & 99.70 & 28 & 107.05 & 23 \\
\hline 44.60 & 16 & 52.40 & 3 & 60.50 & 27 & 67.80 & 70 & 77.33 & 24 & 84.13 & 84 & 92.10 & 7 & 99.80 & 42 & 107.10 & 32 \\
\hline 44.70 & 31 & 52.50 & 6 & 60.60 & 20 & 67.90 & 72 & 77.41 & 11 & 84.21 & 79 & 92.20 & 13 & 99.90 & 35 & 107.20 & 38 \\
\hline 44.80 & 51 & 52.60 & 9 & 60.70 & 13 & 68.00 & 67 & 77.49 & 15 & 84.29 & 78 & 92.30 & 13 & 100.00 & 28 & 107.30 & 20 \\
\hline 44.90 & 47 & 53.00 & 15 & 60.80 & 15 & 68.10 & 65 & 77.56 & 22 & 84.37 & 91 & 92.40 & 8 & 100.10 & 18 & 107.40 & 25 \\
\hline 45.00 & 17 & 53.10 & 7 & 60.90 & 20 & 68.20 & 76 & 77.64 & 27 & 84.45 & 82 & 92.60 & 12 & 100.20 & 23 & 107.50 & 16 \\
\hline 45.10 & 18 & 53.20 & 5 & 61.00 & 8 & 68.30 & 75 & 77.72 & 19 & 84.53 & 60 & 92.70 & 28 & 100.30 & 30 & 107.60 & 16 \\
\hline 45.20 & 55 & 53.30 & 4 & 61.10 & 10 & 68.40 & 72 & 77.80 & 19 & 84.60 & 75 & 92.80 & 23 & 100.40 & 33 & 107.70 & 31 \\
\hline 45.30 & 40 & 53.40 & 1 & 61.20 & 5 & 68.50 & 91 & 77.88 & 23 & 84.68 & 66 & 92.90 & 23 & 100.55 & 22 & 107.80 & 26 \\
\hline 45.40 & 10 & 53.50 & 4 & 61.30 & 2 & 68.60 & 30 & 77.96 & 15 & 84.76 & 66 & 93.00 & 26 & 100.60 & 25 & 107.90 & 21 \\
\hline 45.50 & 9 & 53.60 & 3 & 61.40 & 5 & 68.70 & 39 & 78.03 & 14 & 84.84 & 68 & 93.10 & 22 & 100.70 & 30 & 108.00 & 24 \\
\hline 45.60 & 14 & 53.70 & 5 & 61.50 & 2 & 68.80 & 32 & 78.11 & 11 & 84.92 & 68 & 93.20 & 20 & 100.80 & 39 & 108.10 & 22 \\
\hline 45.70 & 30 & 53.80 & 5 & 61.60 & 13 & 68.90 & 32 & 78.27 & 19 & 85.00 & 78 & 93.30 & 11 & 100.90 & 35 & 108.20 & 23 \\
\hline 45.80 & 27 & 53.90 & 3 & 61.70 & 10 & 69.10 & 47 & 78.35 & 8 & 85.10 & 41 & 93.40 & 11 & 101.00 & 22 & 108.30 & 45 \\
\hline 45.90 & 35 & 54.00 & 0 & 61.80 & 9 & 69.20 & 30 & 78.42 & 7 & 85.20 & 67 & 93.50 & 18 & 101.10 & 12 & 108.40 & 35 \\
\hline 46.00 & 31 & 54.10 & 0 & 61.90 & 5 & 69.30 & 23 & 78.50 & 9 & 85.30 & 63 & 93.60 & 26 & 101.20 & 17 & 108.55 & 31 \\
\hline 46.10 & 33 & 54.20 & 0 & 62.00 & 7 & 69.40 & 22 & 78.58 & 19 & 85.40 & 62 & 93.70 & 16 & 101.30 & 25 & 108.60 & 28 \\
\hline 46.20 & 48 & 54.30 & 0 & 62.10 & 7 & 69.50 & 41 & 78.66 & 27 & 85.50 & 48 & 93.80 & 13 & 101.40 & 16 & 108.70 & 19 \\
\hline 46.30 & 44 & 54.40 & 1 & 62.20 & 9 & 69.60 & 61 & 78.74 & 8 & 85.60 & 50 & 93.90 & 10 & 101.50 & 19 & 108.80 & 22 \\
\hline 46.40 & 40 & 54.50 & 0 & 62.30 & 9 & 69.70 & 60 & 78.82 & 17 & 85.70 & 62 & 94.05 & 11 & 101.60 & 31 & 108.90 & 40 \\
\hline 46.50 & 63 & 54.60 & 0 & 62.40 & 18 & 69.80 & 58 & 78.89 & 16 & 85.80 & 47 & 94.10 & 8 & 101.70 & 14 & 109.00 & 32 \\
\hline 46.60 & 57 & 54.70 & 0 & 62.50 & 13 & 69.90 & 44 & 78.97 & 15 & 85.90 & 42 & 94.17 & 12 & 101.80 & 35 & 109.10 & 26 \\
\hline 46.70 & 51 & 54.80 & 0 & 62.60 & 11 & 70.00 & 14 & 79.05 & 9 & 86.00 & 50 & 94.24 & 16 & 101.90 & 40 & 109.20 & 7 \\
\hline 46.80 & 15 & 54.90 & 1 & 62.70 & 13 & 70.10 & 51 & 79.13 & 7 & 86.10 & 61 & 94.31 & 20 & 102.05 & 48 & 109.30 & 11 \\
\hline 46.90 & 3 & 55.00 & 12 & 62.80 & 29 & 70.20 & 22 & 79.21 & 11 & 86.20 & 71 & 94.38 & 41 & 102.10 & 30 & 109.40 & 19 \\
\hline 47.00 & 28 & 55.10 & 9 & 62.90 & 10 & 70.30 & 21 & 79.29 & 6 & 86.30 & 57 & 94.45 & 41 & 102.20 & 57 & 109.50 & 18 \\
\hline 47.10 & 36 & 55.20 & 8 & 63.00 & 12 & 70.40 & 51 & 79.44 & 8 & 86.40 & 65 & 94.55 & 22 & 102.30 & 53 & 109.60 & 10 \\
\hline 47.20 & 10 & 55.30 & 3 & 63.10 & 4 & 70.60 & 85 & 79.52 & 19 & 86.60 & 42 & 94.60 & 21 & 102.40 & 48 & 109.70 & 32 \\
\hline 47.30 & 3 & 55.40 & 1 & 63.20 & 4 & 70.70 & 51 & 79.60 & 16 & 86.70 & 42 & 94.70 & 25 & 102.50 & 31 & 109.80 & 33 \\
\hline 47.40 & 5 & 55.50 & 1 & 63.30 & 1 & 70.80 & 74 & 79.68 & 18 & 86.80 & 40 & 94.80 & 41 & 102.60 & 42 & 109.90 & 9 \\
\hline 47.50 & 27 & 55.60 & 2 & 63.40 & 0 & 70.90 & 67 & 79.75 & 8 & 86.90 & 30 & 94.90 & 35 & 102.70 & 40 & 110.05 & 10 \\
\hline 47.60 & 13 & 55.70 & 1 & 63.50 & 0 & 71.00 & 74 & 79.88 & 8 & 87.00 & 29 & 95.00 & 27 & 102.80 & 37 & 110.10 & 11 \\
\hline 47.70 & 31 & 55.80 & $i$ & 63.60 & 0 & 71.10 & 72 & 79.91 & 14 & 87.10 & 33 & 95.10 & 26 & 102.90 & 34 & 110.20 & 16 \\
\hline 47.80 & 26 & 55.90 & 0 & 63.70 & 0 & 71.20 & 69 & 79.99 & 11 & 87.20 & 14 & 95.20 & 25 & 103.00 & 30 & 110.30 & 16 \\
\hline 47.90 & 24 & 56.00 & 2 & 63.80 & 0 & 71.30 & 67 & 80.07 & 3 & 87.30 & 37 & 95.30 & 36 & 103.10 & 36 & 110.40 & 6 \\
\hline 48.00 & 25 & 56.10 & 0 & 63.90 & 0 & 71.40 & 58 & 80.15 & 6 & 87.40 & 27 & 95.40 & 27 & 103.20 & 27 & 110.50 & 0 \\
\hline 48.10 & 45 & 56.20 & 0 & 64.00 & 3 & 71.50 & 66 & 80.22 & 25 & 87.50 & 36 & 95.50 & 34 & 103.30 & 31 & 110.60 & 7 \\
\hline 48.20 & 25 & 56.30 & 1 & 64.10 & 2 & 71.60 & 64 & 80.30 & 11 & 87.60 & 28 & 95.60 & 35 & 103.40 & 23 & 110.70 & 9 \\
\hline 48.30 & 28 & 56.40 & 0 & 64.20 & 0 & 71.70 & 72 & 80.38 & 33 & 87.70 & 30 & 95.70 & 18 & 103.55 & 22 & 110.80 & 15 \\
\hline 48.40 & 12 & 56.50 & 3 & 64.30 & 9 & 71.80 & 56 & 80.46 & 24 & 87.80 & 22 & 95.80 & 22 & 103.60 & 16 & 110.90 & 10 \\
\hline 48.50 & 20 & 56.60 & 1 & 64.40 & 9 & 71.90 & 71 & 80.61 & 33 & 87.90 & 22 & 95.90 & 28 & 103.65 & 14 & 111.00 & 13 \\
\hline 48.60 & 13 & 56.70 & 0 & 64.50 & 10 & 72.10 & 43 & 80.69 & 28 & 88.10 & 28 & 96.05 & 28 & 103.70 & 28 & 111.10 & 12 \\
\hline 48.70 & 17 & 56.80 & 1 & 64.60 & 9 & 72.20 & 52 & 80.77 & 17 & 88.20 & 38 & 96.10 & 17 & 103.75 & 10 & 111.25 & 16 \\
\hline 48.80 & 23 & 56.90 & 2 & 64.70 & 7 & 72.30 & 42 & 80.85 & 26 & 88.30 & 19 & 96.20 & 26 & 103.80 & 5 & 111.30 & 16 \\
\hline 48.90 & 20 & 57.00 & 1 & 64.80 & 7 & 72.40 & 41 & 80.93 & 22 & 88.40 & 8 & 96.30 & 22 & 103.85 & 16 & 111.40 & 17 \\
\hline 49.00 & 30 & 57.10 & 1 & 64.90 & 5 & 72.50 & 43 & 81.01 & 30 & 88.50 & 12 & 96.40 & 39 & 103.90 & 11 & 111.50 & 19 \\
\hline 49.10 & 22 & 57.20 & 1 & 65.00 & 10 & 72.60 & 60 & 81.08 & 33 & 88.60 & 11 & 96.50 & 29 & 103.95 & 10 & 111.60 & 36 \\
\hline 49.20 & 21 & 57.30 & 3 & 65.10 & 17 & 72.70 & 66 & 81.16 & 34 & 88.70 & 16 & 96.60 & 21 & 104.00 & 12 & 111.70 & 30 \\
\hline 49.30 & 26 & 57.40 & 4 & 65.20 & 30 & 72.80 & 51 & 81.24 & 32 & 88.80 & 14 & 96.70 & 26 & 104.05 & 40 & 111.80 & 32 \\
\hline 49.40 & 16 & 57.50 & 2 & 65.30 & 24 & 72.90 & 46 & 81.32 & 23 & 88.90 & 11 & 96.80 & 23 & 104.10 & 31 & 111.90 & 32 \\
\hline 49.50 & 18 & 57.60 & 1 & 65.35 & 8 & 73.00 & 50 & 81.40 & 39 & 89.00 & 15 & 96.90 & 22 & 104.20 & 28 & 112.00 & 39 \\
\hline 49.60 & 14 & 57.70 & 2 & 65.40 & 8 & 73.10 & 68 & 81.48 & 37 & 89.10 & 15 & 97.00 & 14 & 104.30 & 36 & 112.10 & 34 \\
\hline 49.70 & 11 & 57.80 & 1 & 65.45 & 11 & 73.20 & 87 & 81.55 & 15 & 89.20 & 21 & 97.10 & 22 & 104.40 & 42 & 112.20 & 53 \\
\hline
\end{tabular}


Table 1 (continued).

\begin{tabular}{|c|c|c|c|c|c|c|c|c|c|c|c|c|c|c|c|c|c|}
\hline $\begin{array}{l}\text { Depth } \\
\text { (mbsf) }\end{array}$ & $\mathrm{C} \%$ & $\begin{array}{l}\text { Depth } \\
\text { (mbsf) }\end{array}$ & C \% & $\begin{array}{l}\text { Depth } \\
\text { (mbsf) }\end{array}$ & C \% & $\begin{array}{l}\text { Depth } \\
\text { (mbsf) }\end{array}$ & $\mathrm{C} \%$ & $\begin{array}{l}\text { Depth } \\
\text { (mbsf) }\end{array}$ & $\mathrm{C} \%$ & $\begin{array}{l}\text { Depth } \\
\text { (mbsf) }\end{array}$ & C \% & $\begin{array}{l}\text { Depth } \\
\text { (mbsf) }\end{array}$ & C \% & $\begin{array}{l}\text { Depth } \\
\text { (mbsf) }\end{array}$ & C \% & $\begin{array}{l}\text { Depth } \\
\text { (mbsf) }\end{array}$ & C \% \\
\hline 112.30 & 25 & 114.50 & 67 & 116.80 & 93 & 118.90 & 70 & 121.10 & 55 & 123.20 & 24 & 125.30 & 79 & 127.40 & 8 & 129.60 & 11 \\
\hline 112.40 & 52 & 114.60 & 69 & 116.90 & 92 & 119.00 & 53 & 121.20 & 36 & 123.30 & 17 & 125.40 & 90 & $127.60^{\circ}$ & 60 & 129.70 & 16 \\
\hline 112.50 & 61 & 114.70 & 71 & 117.00 & 75 & 119.10 & 67 & 121.30 & 31 & 123.40 & 15 & 125.50 & 92 & 127.70 & 71 & 129.80 & 8 \\
\hline 112.60 & 8 & 114.80 & 71 & 117.10 & 74 & 119.20 & 70 & 121.40 & 21 & 123.50 & 16 & 125.60 & 87 & 127.80 & 70 & 129.90 & 6 \\
\hline 112.70 & 11 & 115.10 & 62 & 117.20 & 73 & 119.30 & 84 & 121.50 & 12 & 123.60 & 15 & 125.70 & 94 & 127.90 & 59 & 130.00 & 4 \\
\hline 112.80 & 13 & 115.20 & 56 & 117.30 & 62 & 119.40 & 93 & 121.60 & 17 & 123.70 & 23 & 125.80 & 98 & 128.00 & 62 & 130.10 & 9 \\
\hline 112.90 & 7 & 115.30 & 58 & 117.40 & 23 & 119.60 & 92 & 121.70 & 24 & 123.80 & 40 & 125.90 & 97 & 128.10 & 60 & 130.20 & 13 \\
\hline 113.00 & 14 & 115.40 & 44 & 117.50 & 24 & 119.70 & 76 & 121.80 & 23 & 123.90 & 48 & 126.10 & 97 & 128.20 & 60 & 130.30 & 25 \\
\hline 113.10 & 16 & 115.50 & 64 & 117.60 & 24 & 119.80 & 68 & 121.90 & 32 & 124.00 & 68 & 126.20 & 95 & 128.30 & 64 & 130.40 & 35 \\
\hline 113.20 & 16 & 115.60 & 58 & 117.70 & 51 & 119.90 & 73 & 122.00 & 37 & 124.10 & 79 & 126.30 & 94 & 128.40 & 67 & 130.50 & 38 \\
\hline 113.30 & 13 & 115.70 & 87 & 117.80 & 43 & 120.00 & 70 & 122.10 & 49 & 124.20 & 87 & 126.40 & 93 & 128.50 & 38 & 130.60 & 25 \\
\hline 113.40 & 15 & 115.80 & 74 & 117.90 & 46 & 120.10 & 71 & 122.20 & 29 & 124.30 & 63 & 126.50 & 88 & 128.60 & 64 & 130.70 & 52 \\
\hline 113.60 & 34 & 115.90 & 80 & 118.10 & 66 & 120.20 & 62 & 122.30 & 25 & 124.40 & 75 & 126.60 & 46 & 128.70 & 70 & 130.80 & 34 \\
\hline 113.70 & 51 & 116.00 & 68 & 118.20 & 77 & 120.30 & 36 & 122.40 & 13 & 124.60 & 82 & 126.70 & 31 & 128.80 & 72 & 130.90 & 22 \\
\hline 113.80 & 36 & 116.10 & 70 & 118.30 & 75 & 120.40 & 50 & 122.50 & 8 & 124.70 & 56 & 126.80 & 78 & 128.90 & 60 & 131.00 & 4 \\
\hline 113.90 & 74 & 116.20 & 65 & 118.40 & 82 & 120.50 & 61 & 122.60 & 10 & 124.80 & 68 & 126.90 & 91 & 129.10 & 31 & 131.10 & 6 \\
\hline 114.00 & 31 & 116.30 & 67 & 118.50 & 72 & 120.60 & 75 & 122.70 & 36 & 124.90 & 82 & 127.00 & 96 & 129.20 & 12 & 131.25 & 15 \\
\hline 114.10 & 37 & 116.40 & 57 & 118.60 & 80 & 120.70 & 68 & 122.80 & 28 & 125.00 & 86 & 127.10 & 88 & 129.30 & 29 & 131.30 & 4 \\
\hline 114.20 & 59 & 116.60 & 72 & 118.70 & 84 & 120.80 & 52 & 122.90 & 37 & 125.10 & 90 & 127.20 & 70 & 129.40 & 25 & 131.40 & 13 \\
\hline 114.30 & 64 & 116.70 & 86 & 118.80 & 70 & 120.90 & 79 & 123.10 & 31 & 125.20 & 92 & 127.30 & 18 & 129.50 & 7 & 131.50 & 14 \\
\hline 114.40 & 66 & & & & & & & & & & & & & & & & \\
\hline
\end{tabular}

Table 2. Name, depth, and estimated ages of the units described from the abundance of Coccolithus pelagicus.

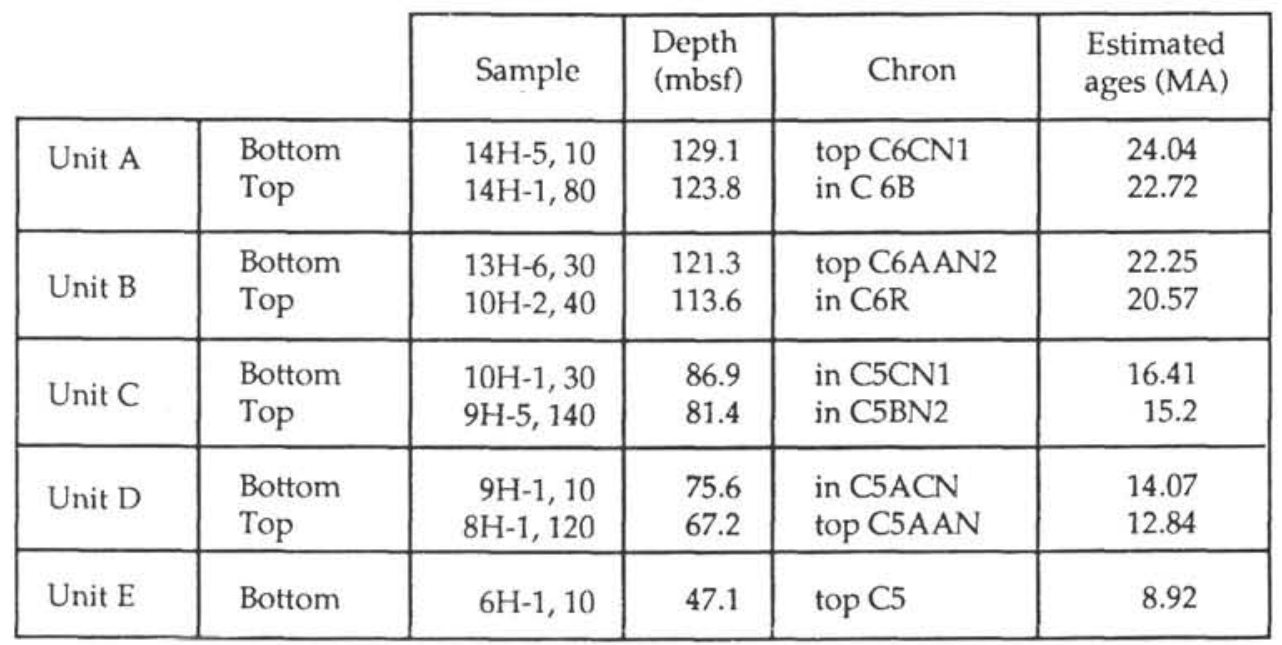

Note: Taken from percentages greater than the average (34\%).

with frequencies close to those of orbital cycles 123 and $95 \mathrm{k} . \mathrm{y}$ and perhaps 413 k.y. Frequency not explained by the Milankovitch theory of climate is also present ( $200 \mathrm{k} . \mathrm{y}$.). An orbital forcing in the series expresses the influence of climate variations on the phytoplankton of the Kerguelen Plateau during the Miocene. Most of the variations recorded by the calcareous nannoplankton at Kerguelen Plateau are of a longer scale, however.

This study essentially demonstrates the great potential that quantitative studies of calcareous nannofossil assemblages have for delineating the paleoceanographic and paleoclimatic evolution of the Miocene of the southern oceans.

\section{ACKNOWLEDGMENTS}

We are thankful to J. Imbrie and W. A. Berggren for helpful discussions and suggestions, and to W. A. Berggren, J. Imbrie, and an anonymous reviewer for reviewing early and last versions of the manuscript. Financial support from the Bureau de Recherches Géologiques et Minières, Orléans, France, is gratefully acknowledged.

\section{REFERENCES}

Berger, A. L., 1977. Support for the astronomical theory of climatic changes. Nature, 269:44-45.

Berggren, W. A., Kent, D. V., and Van Couvering, J. A., 1985. The Neogene: Part 2. Neogene geochronology and chronostratigraphy. In Snelling, N. J. (Ed.), The Chronology of the Geological Record. Geol. Soc. London Mem., 10:211-260.

Bukry, D., 1972. Further comments on coccolith stratigraphy, Leg 12, DSDP. In Laughton, A. S., Berggren, W. A., et al., Init. Repts. DSDP, 12: Washington (U.S. Govt. Printing Office), 1071-1083. , 1976. Silicoflagellate and coccolith stratigraphy, Norwegian-Greenland Sea, Deep Sea Drilling Project Leg 38. In Talwani, M., Udintsev, G., et al., Init. Repts. DSDP, 38: Washington (U.S. Govt. Printing Office), 843-855.

1980. Coccolith stratigraphy, tropical eastern Pacific Ocean, Deep Sea Drilling Project Leg 54. In Rosendahl, B. R., Hekinian, R., et al., Init. Repts. DSDP, 54: Washington (U.S. Govt. Printing Office), 535-543.

Gambéroni, L., 1979. Quelques éléments sur l'hydrologie des océans Indien Sud et Antarctique (secteur Indien). Mem. Mus. Nat. Hist. Nat., Ser. C, 47:21-31. 
Geitzenauer, K. R., Roche, M. B., and McIntyre, A., 1976. Modern Pacific coccolith assemblages: derivation and application to late Pleistocene paleotemperature analysis. In Cline, R. M., and Hays, J. D. (Eds.), Investigation of Late Quaternary Paleoceanography and Paleoclimatology. Mem. Geol. Soc. Am., 145:423-448.

Haq, B. U., 1980. Biogeographic history of Miocene calcareous nannoplankton and paleoceanography of the Atlantic Ocean. Micropaleontology, 26:414-443.

Hays, J. D., Imbrie, J., and Shackleton, N. J., 1976. Variations in the earth's orbit: pacemaker of the ice ages. Science, 194:1121-1132.

Hays, J. D., Lozano, J. A., Shackleton, N. J., and Irving, G., 1976. Reconstruction of the Atlantic and western Indian Ocean sectors of the 18,000 B.P. Antarctic Ocean. In Cline, R. M., and Hays, J. D. (Eds.), Investigations of Late Quaternary Paleoceanography and Paleoclimatology: Mem. Geol. Soc. Am., 145:337-372.

Herbert, T. D., and Fischer, A. G., 1986. Milankovitch climatic origin of mid-Cretaceous black shale rhythms in central Italy. Nature, 321:739-742.

Honjo, S., 1976. Coccoliths: production, transportation and sedimentation. Mar. Micropaleontol., 1:65-79.

in press. Particle fluxes and modern sedimentation in the Polar Oceans. In Smith, W. O., Jr. (Ed.), Polar Oceanography (Part B): New York (Academic Press).

Imbrie, J., Hays, J. D., Martinson, D. G., McIntyre, A., Mix, A. C., Morley, J. J., Pisias, N. G., Prell, W. L., and Shackleton, N. J., 1984. The orbital theory of Pleistocene climate: support from a revised chronology of the marine delta $\delta^{18} \mathrm{O}$ record. In Berger, A., Imbrie, J., Hays, J., Kukla, G., and Saltzman, B. (Eds.), Milankovitch and Climate (Pt. 1): Dordrecht (D. Riedel), 269-305.

Jacques, G., 1978. Groupe Mediprod, Terres Australes et Antarctiques, Campagne Antripod I. Pub. CNEXO: Result. Camp. Mer. 16:1-149.

Kemp, E. M., 1978. Tertiary climatic evolution and vegetation history in the Southeast Indian Ocean Region. Palaeogeogr., Palaeoclimatol., Palaeoecol., 24:169-208.

Kemp, E. M., Frakes, L. A., and Hayes, D. A., 1975. Paleoclimatic significance of diachronous biogenic facies, Leg 28, Deep Sea Drilling Project. In Hayes, D. E., Frakes, L. A., et al., Init. Repts. DSDP, 28: Washington (U.S. Govt. Printing Office), 909-917.

Kennett, J. P., Houtz, R. E., Andrews, P. B., Edwards, A. E., Gostin, V. A., Hajos, M., Hampton, M., Jenkins, D. G., Margolis, S. V., Ovenshine, A. T., and Perch-Nielsen, K., 1975. Cenozoic paleoceanography in the southwest Pacific Ocean, Antarctic glaciation, and the development of the Circum-Antarctic Current. In Kennett, J. P., Houtz, R. E., et al., Init. Repts. DSDP, 29: Washington (U.S. Govt. Printing Office), 1155-1169.

Loutit, T. S., Pisias, N. G., and Kennett, J. P., 1978. Pacific Miocene carbon isotope stratigraphy using benthic foraminifera. Earth Planet. Sci. Lett., 66:48-62.

Matthews, R. K., and Poore, R. Z., 1980. Tertiary $\delta^{18} \mathrm{O}$ record and glacio-eustatic sea-level fluctuations. Geology, 8:501-504.

McIntyre, A., and Bé, A.W.H., 1967. Modern Coccolithophoridae of the Atlantic Ocean. I: Placoliths and Cyrtoliths. Deep-Sea Res. Oceanogr. Abstr., 14:561-597.

Miller, K. G., and Fairbanks, R. G., 1985. Oligocene to Miocene carbon isotope cycles and abyssal circulation changes. In
Sundquist, E. J., and Broecker, W. S. (Eds.), The Carbon Cycle and Atmospheric $\mathrm{CO}_{2}$ : Natural Variations Archean to Present. Am. Geophys. Union Geophys. Monogr., 32:469-486.

Miller, K. G., Feigenson, M. D., Kent, D. V., and Olsson, R. K., 1988. Upper Eocene to Oligocene isotope $\left(^{87} \mathrm{Sr}{ }^{86} \mathrm{Sr}, \delta^{18} \mathrm{O}, \delta^{13} \mathrm{C}\right)$ standard section, Deep Sea Drilling Project Site 522. Paleoceanography, 3:223-233.

Miller, K. G., Wright, J. D., and Brower, A. N., 1989. Oligocene to Miocene stable isotope stratigraphy and planktonic foraminifer biostratigraphy of the Sierra Leone Rise (DSDP Site 366 and ODP Site 667). In Ruddiman, W., Sarnthein, M., et al., Proc. ODP, Sci. Results, 108: College Station, TX (Ocean Drilling Program), 279-294.

Nishida, S., 1979. Atlas of Pacific nannoplankton. News Osaka Micropaleontol. Spec. Pap., 3:1-31.

Okada, H., and McIntyre, A., 1979. Seasonal distribution of the modern Coccolithophores in the western North Atlantic Ocean. Mar. Biol., 54:319-328.

Priddle, J., Hawes, I., Ellis-Evens, J. C., and Smith, T. J., 1986. Antarctic aquatic ecosystems as habitats for phytoplankton. Biol. Rev., 66:199-238.

Savin, S. M., Douglas, R. G., and Stehli, F. G., 1975. Tertiary marine paleotemperatures. Geol. Soc. Am. Bull., 86:1499-1510.

Shackleton, N. J., and Kennett, J. P., 1975. Paleotemperature history of the Cenozoic and the initiation of Antarctic glaciation: oxygen and carbon isotope analyses in DSDP Sites 277,279 , and 281. In Kennett, J. P., Houtz, R. E., et al., Init. Repts. DSDP, 29: Washington (U.S. Govt. Printing Office), 743-755.

Shipboard Scientific Party, 1989. Site 747. In Schlich, R., Wise, S. W., Jr., et al., Proc. ODP, Init. Repts., 120: College Station, TX (Ocean Drilling Program), 89-156.

Tiwary, R. K., 1987. Higher-order eccentricity cycles of the middle and late Miocene climatic variations. Nature, 327:219-220.

Vincent, E., and Berger, W. H., 1985. Carbon dioxide and polar cooling in the Miocene: the Monterey Hypothesis. In Sundquist, E., and Broecker, W. S. (Eds.), The Carbon Cycle and Atmospheric $\mathrm{CO}_{2}$ : Natural Variations Archean to Present.D Am. Geophys. Union, Geophys. Monogr. Ser., 32:455-468.

Vincent, E., Killingley, J. S., and Berger, W. H., 1985. Miocene oxygen and carbon isotope stratigraphy of the tropical Indian Ocean. In Kennett, J. P. (Ed.), The Miocene Ocean: Paleoceanography and Biogeography. Mem. Geol. Soc. Am., 163:103-130.

Woodruff, F., and Savin, S. M., 1985. $\delta^{13} \mathrm{C}$ values of Miocene Pacific benthic foraminifera: correlations with sea level and biological productivity. Geology, 13:119-122.

1989. Miocene deepwater oceanography. Paleoceanography, 4:87-140

Woodruff, F., Savin, S. M., and Douglas, R. G., 1981. Miocene stable isotope record: a detailed deep Pacific Ocean study and its paleoclimatic implications. Science, 212:665-668.

Date of initial receipt: 23 January 1990

Date of acceptance: 28 March 1991

Ms 120B-147 


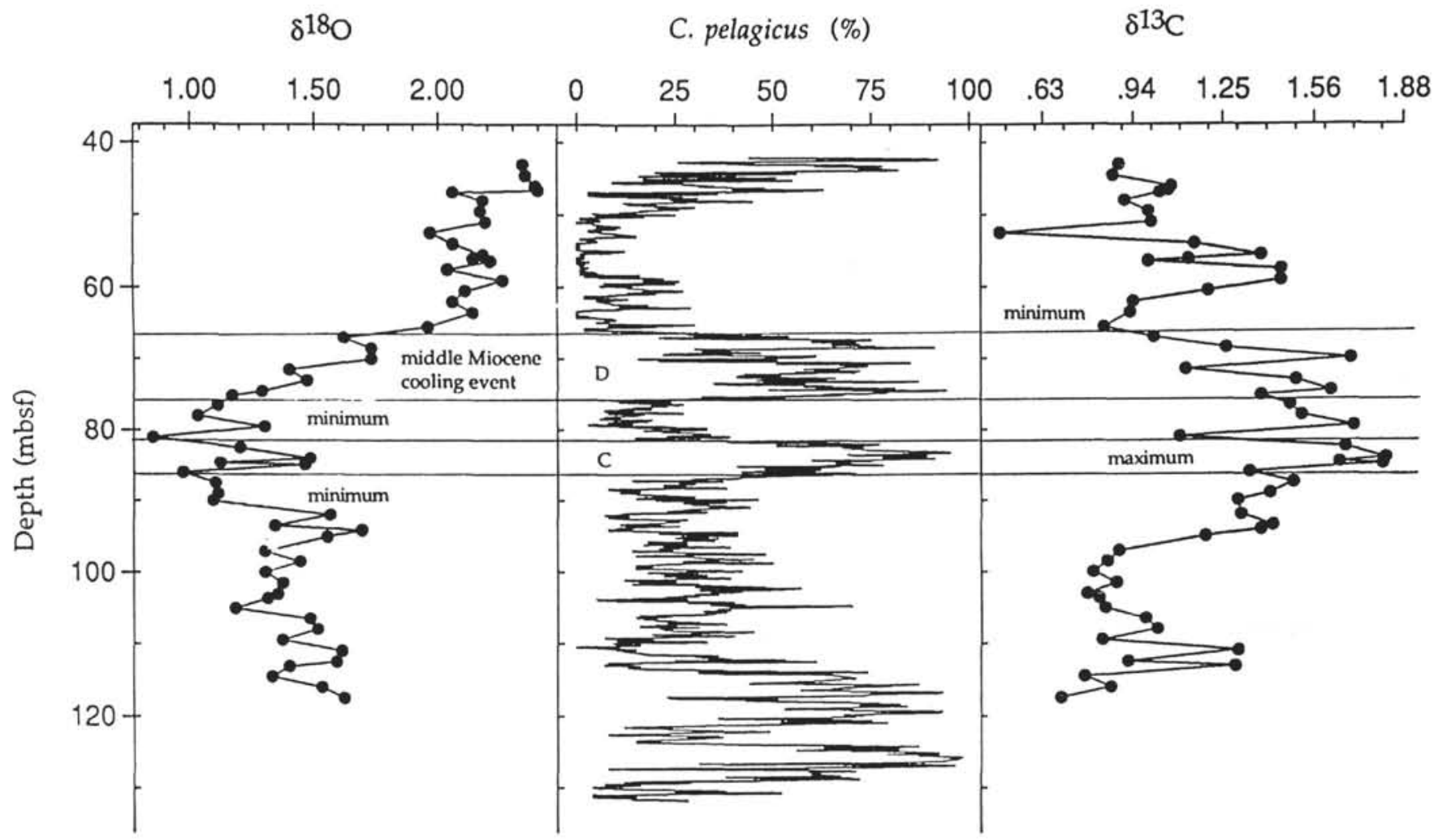

Figure 4. Comparison of the abundance of Coccolithus pelagicus and the stable isotope values from benthic foraminifers, Hole 747A. 


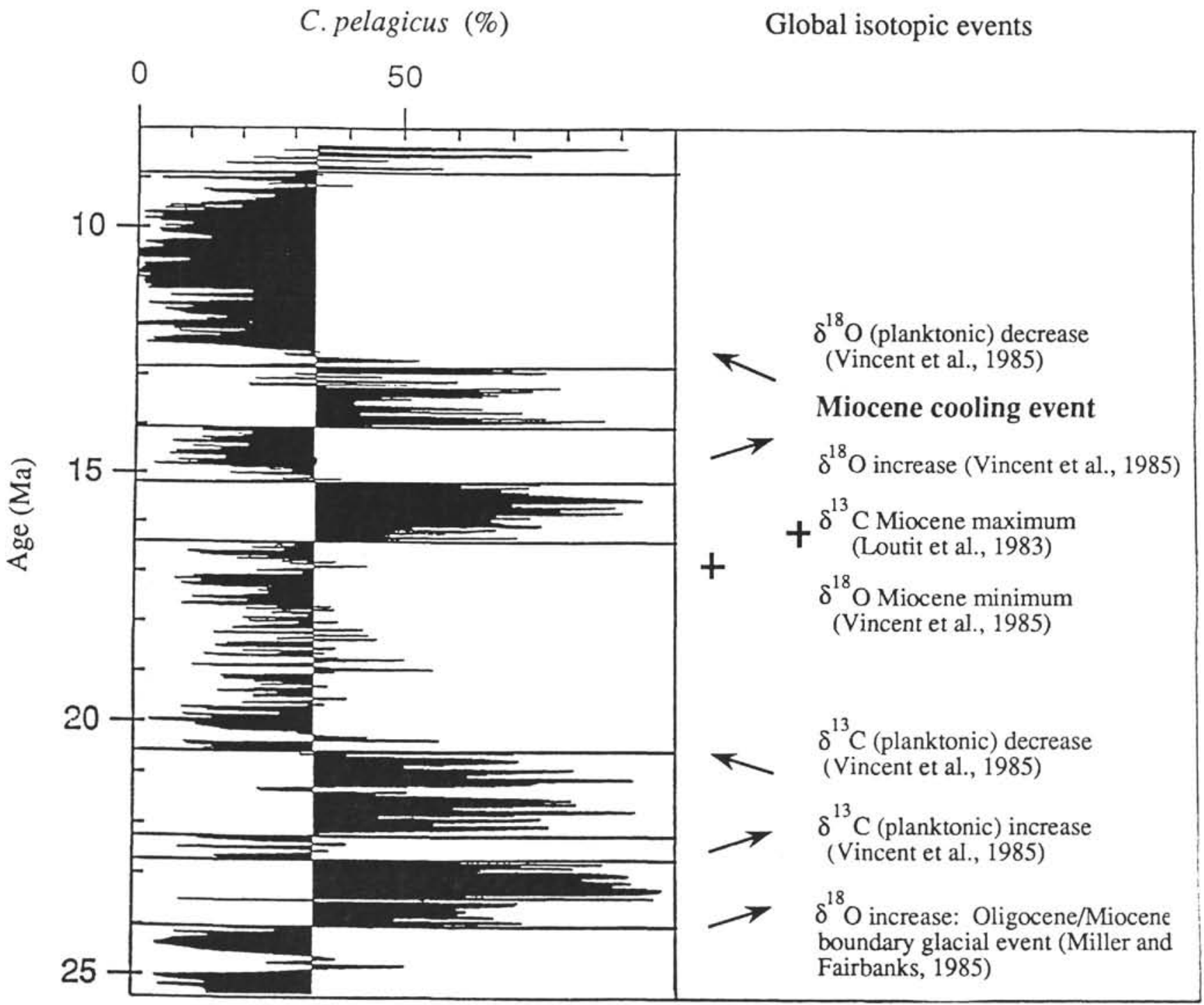

Figure 5. Correlation of the Coccolithus pelagicus units of Site 747 with global isotopic events (data from Wright and Miller, this volume).

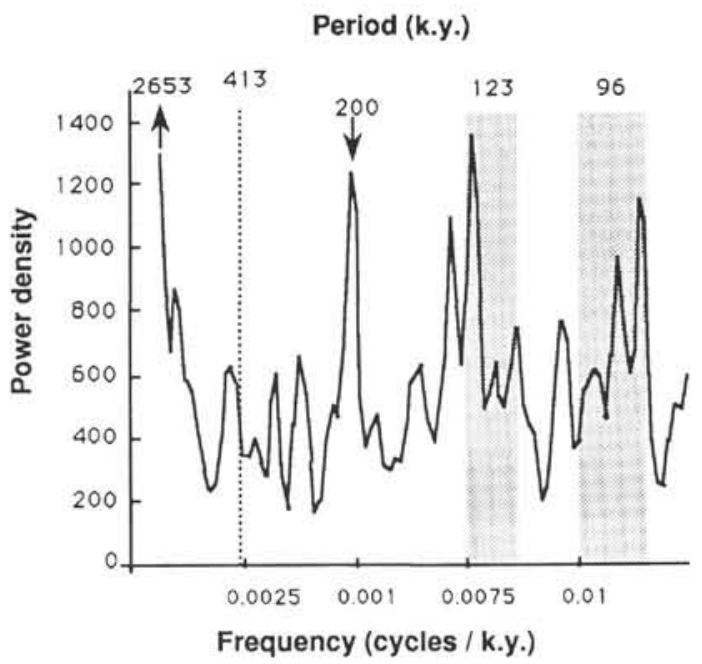

Figure 6. Spectra for the entire C. pelagicus series; the shaded areas correspond to the expected position of the eccentricity cycles $( \pm 7$ k.y.), bandwidth $=0.003$. 
Period (k.y.)
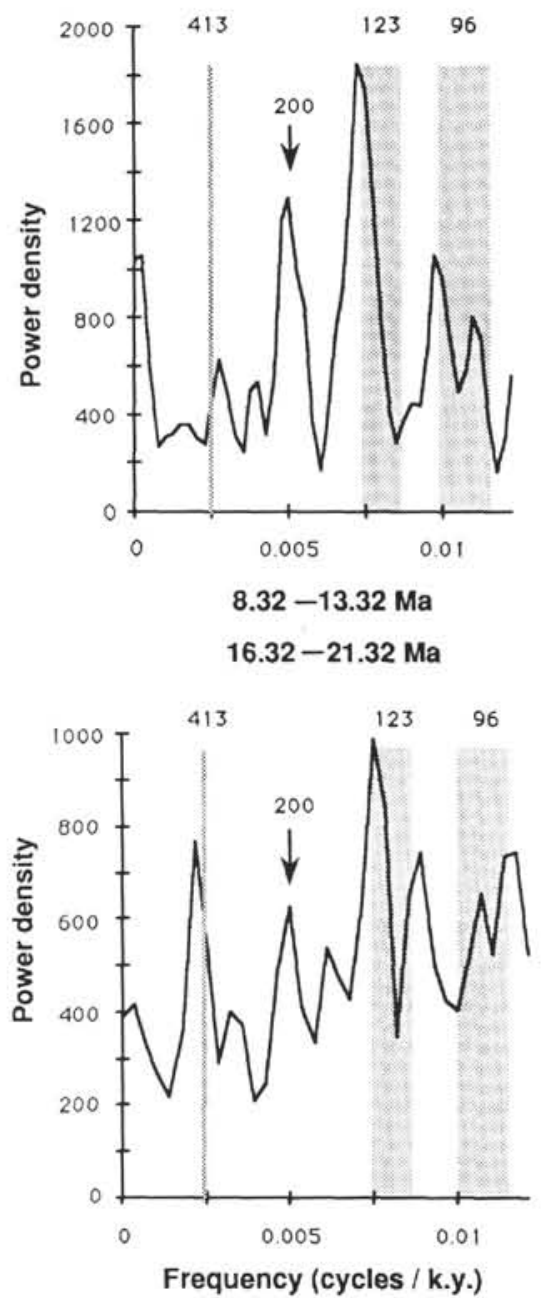

Period (k.y.)
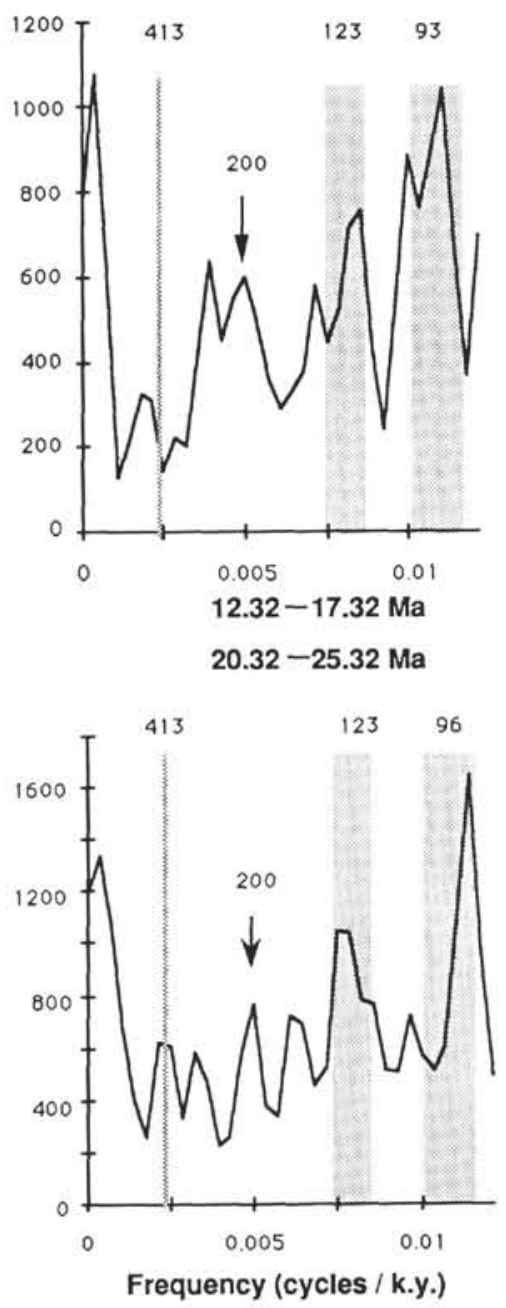

Figure 7. Spectra of four different parts of the $C$. pelagicus series; the shaded areas correspond to the expected frequency values of the eccentricity cycles $( \pm 7$ k.y.), bandwidth $=0.007$. 